\title{
Peran Dana Zakat Produktif dalam Meningkatkan Pendapatan Mustahik
}

\author{
Sopia Kholilah Siregar'1, Darwis Harahap², Rini Hayati Lubis ${ }^{3}$ \\ 1,2,Institut Agama Islam Negeri Padangsidimpuan
}

JL. H.T. Rizal Nurdin Km 4,5 Sihitang Kota Padangsidimpuan Sumatera Utara

Email: sopiakholilahsrg@gmail.com¹, darwisharahap@iain-padangsidimpuan.ac.id ${ }^{2}$, rinihayati@iain-padangsidimpuan.ac.id33

\begin{abstract}
BAZNAS is a zakat management institution formed by the government which has the task of collecting, distributing and utilizing zakat. Zakat can change the role of a mustahiq from helping to being determined by the distribution strategies and programs carried out by zakat managers. This study aims to determine how the role of productive zakat funds in increasing mustahiq income in South Tapanuli BAZNAS. The results of this study indicate that the role of productive zakat in increasing mustahiq income in BAZNAS South Tapanuli has been effective. However, in developing a business, every mustahik has not been realized properly. This is because BAZNAS Tapanuli Selatan only distributes productive zakat and carries out evaluations, while coaching and mentoring are not carried out at all. So it has an impact on the mustahiq who run the business. Mustahiq's skills to manage the business are very lacking, resulting in the business not running.
\end{abstract}

Keywords : BAZNAS, Mustahiq Income, Productive Zakat

\begin{abstract}
ABSTRAK
BAZNAS merupakan lembaga pengelolaan zakat yang dibentuk oleh pemerintah yang mempunyai tugas dalam pengumpulan, pendistribusian dan pendayagunaan zakat. Zakat dapat merubah peran seorang mustahik dari yang dibantu menjadi membantu ditentukan oleh strategi dan program pendistribusian yang dilakukan pengelola zakat. Penelitian ini bertujuan untuk mengetahui bagaimana peran dana zakat produktif dalam meningkatkan pendapatan mustahik di BAZNAS Tapanuli Selatan. Hasil penelitian ini menunjukkan bahwa peran zakat produktif dalam meningkatkan pendapatan mustahik di BAZNAS Tapanuli Selatan sudah efektif. Akan tetapi dalam mengembangkan usaha setiap mustahik belum terealisasikan dengan baik. Hal ini di karenakan BAZNAS Tapanuli Selatan hanya menyalurkan zakat produktif dan melakukan evaluasi saja, sedangkan pembinaan dan pendampingan tidak dilakukan sama sekali. Maka hal itu berdampak pada mustahik yang menjalankan usahanya tersebut. Skill yang dimiliki mustahik untuk mengelola usahanya sangat kurang, sehingga mengakibatkan usaha tersebut tidak berjalan.
\end{abstract}

Kata Kunci : BAZNAS, Pendapatan Mustahik, Zakat Produktif 


\section{PENDAHULUAN}

Zakat menjadi solusi untuk mengatasi problem perekonomian pada setiap negara. Sejak dahulu, Rasulullah SAW sudah mempraktikkan langsung bagaimana zakat memecahkan masalah umat dan menjadi sumber kas negara. Zakat akan efektif jika digunakan untuk mengentaskan kemiskinan. Zakat mempunyai kedudukan signifikan diantaranya sebagai instrumen peningkatan umat Islam, pendidikan/pengetahuan, pengembangan prasarana umum dan pelayanan umum sebagai relevansi kesejahteraan masyarakat Indonesia (Mardani,2011:21).

Salah satu fungsi dari zakat adalah untuk menciptakan kesejahteraan sosial dengan mewujudkan keadilan yang merata diseluruh kalangan umat atau masyarakat. Zakat diharapkan dapat membantu untuk mengentaskan kemiskinan dan mengurangi kesenjangan pendapatan masyarakat. Kewajiban membayar zakat dan penyalurannya yang dilaksanakan secara optimal tidak hanya memberi manfaat keagamaan, melainkan juga dapat memberikan pengaruh yang besar terhadap pemerataan pendapatan bagi seluruh umat Islam (Imas Rosi Nugrahani, 2017:31).

Zakat mempunyai peranan penting agar kesejahteraan masyarakat meningkat. Permasalahan pada zakat perlu memperhatikan keperluan riil yang menerima zakat, kesanggupannya untuk mengelola dan memanfaatkan dana zakat untuk mewujudkan kesejahteraan serta terbebas dari rantai kemiskinan. Ibadah zakat mencakup berbagai aktivitas yang berhubungan dengan kepengurusan zakat, yakni mengumpulkan, mendistribusikan, mengawasi, administrasi serta pertanggungjawaban (Suparman Usman, 2002:163).

Zakat merupakan mengeluarkan sebagian dari harta benda yang dimiliki dan sudah mencapai nisab bagi mustahik. Selain itu, zakat yaitu memindahkan kepemilikan harta untuk mustahik dengan ketentuan tertentu. Zakat termasuk rukun Islam ketiga, dipandang menjadi suatu kewajiban umat Islam. Zakat termasuk sebagai dasar prinsipal untuk menegakkan struktur sosial masyarakat Islam (Yusuf Qardhawi,2005:195).

Tujuan zakat mempunyai target sosial untuk membangun sistem ekonomi yang mempunyai kesejahteraan dunia akhirat. Zakat juga dapat berkontribusi dalam pengentasan kemiskinan. Namun hingga saat ini, pengumpulan dan pemanfaatan dana zakat belum dilakukan secara optimal sebagaimana yang telah dicontohkan oleh Rasulullah dan para Khalifah. Padahal melalui pemberdayaan zakat yang optimal kemiskinan dapat berkurang dengan signifikan. Hanya saja, kemiskinan yang akan diatasi melalui zakat tidak dapat dilakukan hanya memberikan bantuan untuk memenuhi kebutuhan konsumtif saja, tetapi harus lebih kepada pemberdayaan yang menyebabkan golongan miskin keluar dari kemiskinan (Annida Karima Sovia,2020). 
Di Indonesia, pengelolaan zakat terdapat dua macam yaitu dikelola secara konsumtif yang mana dana zakat diberikan kepada mustahik untuk dimanfaatkan langsung. Sedangkan secara produktif yaitu memberikan modal usaha untuk kelancaran usaha ataupun di salurkan dalam bidang pendidikan kewirausahaan agar mustahik mempunyai kemampuan dalam mengelola dana zakat produktif (Arief Mufraini:2008:155). Mengenai pelaksanaan pengelolaan zakat ditentukan dari strategi dan manfaat zakat bagi mustahik.

Keberhasilan pengelolaan dapat di lihat dari adanya perubahan peran seseorang, dari yang awalnya menjadi mustahik dan beralih menjadi muzakki. Untuk merubah peran seorang mustahik dari yang dibantu menjadi yang membantu (muzakki) dalam zakat ditentukan oleh strategi dan program pendistribusian yang dilakukan oleh pengelola zakat. Pengelolaan zakat menjadi penting karena keberhasilan ini dapat dicapai melalui pola pengelolaan zakat secara efektif produktif (Nurlaila, 2020:3).

Pengelolaan zakat di Indonesia di tegaskan pada Undang-Undang Nomor 23 Tahun 2011 bahwa pemerintah mendirikan Badan Amil Zakat Nasional (BAZNAS) pada daerah Pusat, Provinsi serta Kabupaten/Kota. Dalam hal meringankan pekerjaan Badan Amil Zakat Nasional maka di setiap kecamatan di bentuk suatu Unit Pengelola Zakat (UPZ). Tugas menghimpun dan menyalurkan zakat dilakukan oleh dua instansi yaitu BAZ dan LAZ. BAZ merupakan organisasi yang dibentuk pemerintah yang terdiri dari unsur pemerintah dan masyarakat serta mempunyai fungsi penghimpunan, penyaluran dan mendayagunakan. Sedangkan LAZ merupakan lembaga yang di dirikan oleh masyarakat yang bergerak di bidang pendidikan, dakwah, sosial dan kemaslahatan umat.

Badan Amil Zakat Nasional (BAZNAS) Tapanuli Selatan berdiri sejak tahun 2011. Akan tetapi, zakat yang sifatnya produktif mulai di dirikan pada tahun 2013. Dana zakat produktif ini disalurkan kepada 15 Kecamatan di Kabupaten Tapanuli Selatan. BAZNAS Tapanuli Selatan mempunyai motto "Amanah Terjamin, Penyaluran Terukur”. Terdapat tiga aktivitas penting dalam lembaga zakat ini, yaitu menghimpun, mengelola (keuangan) dan mendayagunakan.

Tabel 1

Dana Zakat Produktif BAZNAS Tapanuli Selatan Tahun 2013-2021

\begin{tabular}{|c|c|c|}
\hline No. & Tahun & $\begin{array}{c}\text { Jumlah Zakat } \\
\text { Produktif (Rp) }\end{array}$ \\
\hline 1 & $2013-2014$ & Rp. 20.000.000 \\
\hline 2 & $2015-2016$ & Rp. 50.000.000 \\
\hline 3 & $2017-2018$ & Rp. 20.000.000 \\
\hline 4 & $2019-2020$ & Rp. 25.000.000 \\
\hline 5 & 2021 & Rp. 25.000.000 \\
\hline
\end{tabular}

Sumber data: Wawancara dengan Bapak Ihwan Harahap

JISFIM: Journal of Islamic Social Finance Management, Volume 2, No 2 Tahun 2021 http://jurnal.iain-padangsidimpuan.ac.id/index.php/JISFIM 
Berdasarkan tabel 1 diatas, menunjukkan bahwa perkembangan dana zakat produktif di BAZNAS Tapanuli Selatan dari tahun 2013 sampai 2021 mengalami perubahan yang fluktuasi. Ketika dana yang disalurkan sedikit, pendapatan mustahik meningkat, namun peningkatannya masih tergolong kecil. Akan tetapi, ketika dana yang disalurkan meningkat, usaha yang sedang dijalankan mustahik tidak mengalami perkembangan bahkan tidak berjalan. Seharusnya, peningkatan jumlah dana zakat, memiliki potensi dalam meningkatkan pendapatan mustahik. Hal ini dikarenakan, BAZNAS Tapanuli Selatan hanya sekedar menyalurkan dana zakat tanpa di iringi dengan pembinaan. Tujuan diadakannya pembinaan, agar mustahik mempunyai skill dalam mengelola usahanya. Maka dari itu, program zakat produktif tidak sesuai dengan harapan BAZNAS Tapanuli Selatan dalam mensejahterakan ekonomi mustahik.

BAZNAS Tapanuli Selatan melakukan pembaharuan ditahun 2019 sampai 2021, yaitu menyalurkan dana zakat yang bersifat produktif dalam bentuk usaha berkelompok. Hal ini di karenakan, usaha berkelompok dianggap lebih optimal dibandingkan memberikan dana zakat kepada masing-masing mustahik. Sebagaimana hasil wawancara yang dilakukan oleh peneliti bersama Bapak Misdarwin selaku Sekretaris Pengelola Syariah Tapanuli Selatan mengatakan bahwa zakat produktif mempunyai peran yang sangat penting dalam meningkatkan pendapatan mustahik. Namun, penyaluran dana zakat yang bersifat produktif di BAZNAS Tapanuli Selatan belum optimal. Hal ini dikarenakan, kesungguhan mustahik dalam memanfaatkan dana zakat ini untuk modal usahanya masih kurang. Berdasarkan latar belakang diatas, peneliti tertarik melakukan penelitian lebih lanjut mengenai "Peran Dana Zakat Produktif Dalam Meningkatkan Pendapatan Mustahik (Studi Kasus BAZNAS Tapanuli Selatan)".

\section{METODE PENELITIAN}

Berdasarkan analisis data dalam penelitian ini menggunakan penelitian kualitatif, dengan spesifikasi penelitian lapangan. Lokasi yang menjadi penelitian ini berlangsung adalah (Badan Amil Zakat Nasional) BAZNAS Tapanuli Selatan yang beralamat di Jl. Willem Iskandar Kota Padangsidimpuan. Sumber data dalam penelitian ini ada 2 yaitu Sumber data primer berupa informan yaitu Sekretaris Syariah, Ketua Bidang Penyaluran dan Pendayagunaan zakat dan para mustahik. Sedangkan sumber data sekunder diperoleh dari laporan tahunan BAZNAS Tapanuli Selatan, jurnal penelitian dan buku yang berkaitan dengan peran dana zakat produktif dalam meningkatkan pendapatan mustahik. Teknik pengumpulan data dilakukan melalui wawancara, observasi dan dokumentasi. Sedangkan analisis data dilakukan dengan; a) pengumpulan data, yaitu peneliti melakukan pengumpulan data melalui wawancara dengan pihak pengelola zakat produktif dan para mustahik penerima zakat produktif di BAZNAS Tapanuli Selatan; b) reduksi data yaitu dalam penelitian ini JISFIM: Journal of Islamic Social Finance Management, Volume 2, No 2 Tahun 2021 http://jurnal.iain-padangsidimpuan.ac.id/index.php/JISFIM 
merangkum jawaban dari informan yang menerima dana zakat produktif dan yang mengelola dana zakat produktif BAZNAS Tapanuli Selatan. Kemudian peneliti mengelompokkan jawaban tersebut yang sesuai dengan rumusan masalah penelitian terkait dengan peran dana zakat produktif dalam meningkatkan pendapatan mustahik BAZNAS Tapanuli Selatan; c) display data yaitu dalam penelitian ini, peneliti menyajikan data tersebut pada rumusan masalah penelitian. Berupa bentuk narasi hasil analisis hasil penelitian informan mustahik dan juga berupa bantuan beberapa tabel dan gambar sebagai inti dari hasil penelitian rumusan masalah pada peran dana zakat produktif dalam meningkatkan pendapatan mustahik BAZNAS Tapanuli Selatan; d) penarikan kesimpulan yaitu peneliti menarik kesimpulan dari hasil penelitian, kemudian peneliti melakukan verifikasi melalui bukti-bukti yang menunjukkan valid seperti jawaban dari pihak pengelola zakat di BAZNAS Tapanuli Selatan, dan para mustahik penerima dana zakat produktif ini. Dan pengecekan keabsahan data dengan triangulasi dan ketekunan pengamatan.

\section{HASIL DAN PEMBAHASAN}

\section{Pendapatan Mustahik}

Menurut ilmu ekonomi, pendapatan merupakan nilai maksimum yang dapat dikonsumsi oleh seseorang dalam satu periode. Dengan kata lain pendapatan adalah jumlah harta kekayaan awal periode ditambah keseluruhan hasil yang diperoleh selama satu periode, bukan hanya yang dikonsumsi (Sadono Sukirno,2008:6). Suroto mengemukakan bahwa pendapatan merupakan seluruh penerimaan baik berupa uang maupun barang yang berasal dari pihak lain maupun dari hasil industri yang dinilai atas dasar jumlah uang dari harta yang berlaku saat itu. Dengan demikian merupakan penghasilan yang diterima oleh seseorang dalam jangka waktu tertentu dari hasil usaha yang diperoleh oleh individu atau kelompok yang digunakan untuk memenuhi kebutuhan sehari-harinya (Suroto,2002:26).

Pendapatan adalah penghasilan yang diperoleh seseorang dalam melakukan sebuah pekerjaan. Gunanya untuk memenuhi kebutuhan hidupnya serta keluarganya. Biasanya apabila pendapatan seseorang tinggi maka biasanya orang tersebut relatif mudah dalam memenuhi kebutuhan hidupnya, namun sebaliknya apabila pendapatan seseorang tersebut rendah, maka orang tersebut relatif sulit untuk memenuhi kebutuhannya.

Tingkat pendapatan mempengaruhi tingkat konsumsi masyarakat. Kenyataan menunjukkan bahwa pengeluaran konsumsi meningkat dengan naiknya pendapatan, dan sebaliknya jika pendapatan turun, pengeluaran konsumsi juga turun. Tinggi rendahnya pengeluaran sangat bergantung kepada kemampuan keluarga dalam mengelola penerimaan atau pendapatannya (Mahyu Danil, 2013:9). 


\section{Zakat Produktif}

Menurut bahasa, zakat yaitu tumbuh (numuww) serta bertambah (ziyadah) (Wahbah Al- Zuhayly, 1995:82-85). Dari pengertian secara bahasa dapat diketahui bahwa zakat bermakna tumbuh dan berkembang atau menyucikan dan membersihkan. Sementara Didin Hafiduddin berpendapat bahwa zakat ditinjau dari segala bahasa berarti kebersihan (Didin Hafidhuddin,2002:34). Sedangkan menurut terminology (syara') zakat yaitu hak yang wajib dikeluarkan dari harta setiap muslim. Menurut terminologi fuqaha zakat adalah bagian harta tertentu dan yang diwajibkan Allah untuk diberikan kepada orang-orang fakir (Wahbah AlZuhayly:85).

Produktif diartikan sebagai mendayagunakan kembali suatu dana atau benda yang hasilnya diperoleh dari pendayagunaan tersebut dan dapat digunakan untuk kemaslahatan umat. Zakat produktif merupakan zakat yang diberikan kepada mustahik sebagai modal untuk menjalankan suatu kegiatan ekonomi potensi produktifitas (Asnaini,2008:23). Berdasarkan penjelasan diatas, maka dapat disimpulkan bahwa zakat produktif dimana harta atau dana zakat yang diberikan kepada para mustahik tidak dihabiskan, akan tetapi dikembangkan dan digunakan untuk membantu usaha mereka, sehingga dengan usaha tersebut mereka dapat memenuhi kebutuhan hidup secara terus menerus.

Hakikat zakat merupakan pengelolaan sebagian harta/benda yang diperoleh dari muzakki kemudian disalurkan kepada delapan mustahik yang sudah ditentukan oleh syariat Islam. Manajemen dalam mengelola zakat terdiri dari beberapa kegiatan baik itu penghimpunan, pengelolaan (manajemen), penyaluran (pendistribusian), pemanfaatan serta pertanggungjawaban harta/benda zakat. Tujuan dari adanya penyelenggaraan zakat ini antara lain yaitu; 1) Mengembangkan intervansi terhadap masyarakat ketika membayar zakat berdasarkan syariat Islam; 2) Mengembangkan fungsi serta kedudukan lembaga keagamaan dalam upaya mewujudkan kesejahteraan masyarakat dan keadilan sosial; 3) Meningkatkan hasil guna dan pemanfaatan zakat.

Zakat memerlukan pengelolaan yang baik karena zakat merupakan sumber dana potensial, yang dapat di manfaatkan sebagai upaya untuk mewujudkan kesejahteraan rakyat. Pelaksanaan ibadah zakat melibatkan sejumlah kegiatan yang berkaitan dengan pengelolaan harta benda, mulai dari pengumpulan, pendistribusian, pengawasan, pengadministrasian, dan pertanggungjawaban harta zakat. Dengan demikian untuk terlaksananya ibadah zakat sesuai dengan ketentuan agama, agar tercapai nilai ibadah yang benar, maka mutlak diperlukan pengelolaan zakat yang baik, benar dan professional (Gazi Inayah,2003:217).

Berdasarkan Undang-undang Nomor 38 Tahun 1998 tentang organisasi pengelolaan zakat dapat dilakukan oleh Badan Amil Zakat (BAZ) dan Lembaga Amil Zakat (LAZ). BAZ dan LAZ mempunyai tugas pokok mengumpulkan, mendistribusikan dan mendayagunakan zakat sesuai ketentuan agama. Dalam melaksanakan tugasnya BAZ dan LAZ bertanggung jawab JISFIM: Journal of Islamic Social Finance Management, Volume 2, No 2 Tahun 2021 http://jurnal.iain-padangsidimpuan.ac.id/index.php/JISFIM 
kepada pemerintah sesuai dengan tingkatannya. Syarat terpenting dalam menopang keberhasilan pengelolaan zakat dalam mengimplementasikan tujuan kemasyarakatan adalah penyaluran dan menerapkan yang bagus artinya memberikan zakat kepada yang seharusnya layak sebagai penerima zakat (Muhammad Hadi,2010:81).

\section{Pendayagunaan atau Pemanfaatan Zakat Produktif}

Pemanfaatan berasal dari kata manfaat yang mempunyai arti guna, selain itu pemanfaatan mempunyai kaitan makna yang sama dengan pendayagunaan. Dimana pendayagunaan dapat diartikan dengan daya guna yaitu kemampuan mendatangkan hasil dan manfaat. Pendayagunaan dapat diartikan sebagai pengusahaan agar mampu mendatangkan hasil dan manfaat. Berdasarkan pengertian tersebut, dapat disimpulkan bahwa pemanfaatan atau pendayagunaan dalam konteks zakat adalah zakat yang dikumpulkan kemudian dikelola menjadi suatu usaha agar mampu mendatangkan hasil, guna dan manfaat yang sesuai dengan tujuan penyaluran zakat yaitu menghasilkan penghasilan tetap dan mengentaskan kemiskinan (Lailiyatun,2015:6).

Zakat disamping termasuk dalam kategori ibadah mahdlah juga mempunyai dimensi sosial ekonomi. Oleh karena itu zakat mempunyai peranan yang sangat penting dalam pemberdayaan ekonomi umat dan juga dalam pengentasan kemiskinan. Maka untuk memastikan mampu atau tidaknya zakat tersebut dalam memberdayakan ekonomi dan juga mengentaskan, maka sangat tergantung pada bagaimana sistem distribusi yang diterapkan dan kepada siapa zakat tersebut didistribusikan.

Adapun untuk penyaluran zakat produktif, khususnya untuk pemberdayaan ekonomi, maka pihak yang pertama diberikan adalah kepada fakir dan yang kedua kepada miskin, sehingga tujuan utama pemberian zakat khususnya zakat produktif yaitu untuk mengentaskan kemiskinan dapat terwujud. Bagi pihak penerima zakat telah jelas diatur keberadaannya dalam Al-Quran. Pemanfaatan atau pendayagunaan dana zakat diluar dari ketentuanketentuan yang ada harus mempunyai dasar hukum yang kuat.

Pemanfaatan atau pendayagunaan dana zakat dapat dilakukan sebagai berikut; 1) Pemanfaatan atau pendayagunaan zakat konsumtif dan tradisional, dimana bentuk pemanfaatan atau pendayagunaan dana zakat bersifat pemberian langsung dan hanya bersifat sementara, yang langsung dapat di pakai dan di manfaatkan oleh mustahik; 2) Pemanfaatan dan pendayagunaan dana zakat konsumtif kreatif, misalnya pemberian dana zakat untuk beasiswa dan keperluan alat-alat sekolah; 3) Pemanfaatan dan pendayagunaan produktif tradisional, dalam artian bahwa pemberian dana zakat ini dilakukan dengan cara pemberian barang-barang atau alat produktif yang bertujuan untuk dapat menciptakan suatu usaha atau memberikan lapangan kerja, misalnya pemberian mesin jahit, alat-alat pertanian, sapi, kambing dan lain-lain; 4) Pemanfaatan dan pendayagunaan dana zakat produktif kreatif, yaitu dalam bentuk pemberian dana zakat berupa bantuan modal, yang di gunakan untuk

JISFIM: Journal of Islamic Social Finance Management, Volume 2, No 2 Tahun 2021 http://jurnal.iain-padangsidimpuan.ac.id/index.php/JISFIM 
membuat suatu usaha atau sebagai tambahan modal bagi usaha yang telah berjalan (Sintha Dwi Wulansari,2013:24-25).

\section{Model Pendistribusian Zakat Produktif}

Al-Quran menjelaskan, bahwa zakat harus disalurkan hanya untuk delapan golongan orang seperti firman Allah SWT dalam Surah At-Taubah ayat 6o. Secara umum, pesan pokok dalam ayat tersebut adalah mereka secara ekonomi kekurangan. Oleh karena itu, didalam pendistribusiannya hendaknya mengendepankan upaya merubah mereka yang memang membutuhkan, sehingga setelah menerima zakat, dalam periode tertentu berubah menjadi pembayar zakat.

Kata distribusi sendiri berasal dari bahasa Inggris yaitu distribute yang berarti pembagian atau penyaluraan. Secara terminology distribusi adalah penyaluran (pembagian) kepada orang banyak atau beberapa tempat. Jadi, dapat ditarik kesimpulan bahwa pendistribusian zakat produktif adalah penyaluran dana zakat kepada orang-orang yang berhak menerima zakat (mustahik).

Pendistribusian dana zakat berfungsi sebagai upaya untuk mengurangi perbedaan antara kaya dan miskin karena bagian harta kekayaan orang kaya membantu dan menumbuhkan kehidupan ekonomi yang miskin, sehingga keadaan ekonominya dapat di perbaiki. Oleh karena itu, zakat berfungsi sebagai sarana jaminan sosial dan persatuan masyarakat dalam memenuhi kebutuhan-kebutuhan individu dan memberantas kemiskinan umat manusia, dalam hal ini zakat merupakan bukti kepedulian sosial (Teguh Ansori,2018:172).

Dalam melakukan pendistribusian dana zakat produktif, maka dapat dilakukan dengan beberapa metode antara lain sebagai berikut; 1) Sistem Qard Al-Hasaan, Qard $\quad A l$ Hasan merupakan pinjaman lunak tanpa bunga (Mohammad Thoriquddin,2015:88). Model pendistribusian dengan menggunakan sistem qardhul hasan ini dilakukan dengan cara memberikan pinjaman modal usaha dengan mengembalikan pokok tanpa ada tambahan jasa. Adapun pokok pinjaman atau modal memang di kembalikan oleh mustahik kepada lembaga amil zakat, namun tidak berarti bahwa modal itu tidak lagi menjadi hak mustahik tersebut. Artinya modal masih dapat dikembalikan lagi kepada mustahik yang bersangkutan untuk di kembangkan lagi atau bisa juga di gulirkan ke mustahik lain; 2) Sistem Mudharabah, model pendistribusian dengan sistem mudharabah ini dilakukan dengan cara penanaman modal usaha dengan konskuensi bagi hasil. Sistem ini hampir sama dengan sistem qardhul hasan, akan tetapi terdapat perbedaan yaitu terletak pada pembagian bagi hasil dari usaha antara mustahik dan amil; 3) Sistem Hibah atau In Kind, model pendistribusian dengan sistem hibah dilakukan dengan cara dana zakat di berikan dalam bentuk alat-alat produksi yang dibutuhkan oleh mustahik/kaum ekonomi lemah yang ingin berproduksi, baik mereka yang 
baru mulai usahanya maupun yang telah berusaha untuk pengembangan usaha yang telah ada.

\section{Peran dana zakat Produktif Dalam Meningkatkan Pendapatan Mustahik Di BAZNAS Tapanuli Selatan}

Zakat merupakan salah satu instumen dalam menurunkan tingkat kemiskinan. Karena dengan adanya zakat, harta tidak akan menumpuk disatu golongan saja. Melainkan dapat terbagi ke golongan-golongan lain termasuk golongan yang membutuhkan (mustahik). Zakat produktif adalah satu cara agar penyaluran zakat agar harta tidak menumpuk di satu kalangan saja.

BAZNAS Tapanuli Selatan merupakan lembaga yang menyalurkan zakat produktif. Terdapat beberapa kebijakan yang dibuat untuk dijadikan pedoman di BAZNAS Tapanuli Selatan dalam menyalurkan zakat produktif. Tujuan BAZNAS Tapanuli Selatan adalah menjadikan mustahik menjadi seorang muzakki, hingga ia tidak tenggelam dalam kemiskinannya namun dapat meningkatkan pendapatannya.

Dana zakat poduktif ditujukan untuk modal usaha atau tambahan modal usaha. Jadi dana yang diberikan tidak habis begitu saja, melainkan dana akan dikelola menjadi usaha dan akan menghasilkan pendapatan. Pendapatan tersebut yang akan memenuhi kebutuhan hidup dan mensejahterakan perekonomian keluarga mustahik. Mustahik yang mengelola dana zakat produktif untuk dijadikan usaha akan menghasilkan tambahan pendapatan, hingga pendapatannya meningkat.

Hasil penelitian ini menujukkan bahwa peran dana zakat produktif dalam meningkatkan pendapatan mustahik belum efektif. Sebab, peningkatan pendapatan pada mustahik masih tergolong kecil yaitu dibawah Rp.1.ooo.ooo (satu juta rupiah). Sejak 2013 sampai 2019, penyaluran zakat produktif hanya sekedar disalurkan tanpa adanya pembinaan sama sekali, sehingga mustahik tidak mempunyai skill dalam mengelola usahanya. Berdasarkan hasil wawancara dan observasi yang dilakukan oleh peneliti, mustahik yang menerima zakat produktif sebagai modal usaha tidak berhasil dalam mengembangkan usahanya. Walaupun dana zakat produktif yang disalurkan sedikit bahkan banyak, tetap harus diadakan pembinaan kepada mustahik.

Tabel 2

Data Pertambahan Pendapatan Mustahik

\begin{tabular}{|l|l|l|l|}
\hline $\begin{array}{l}\text { Nama } \\
\text { mustahik }\end{array}$ & Jenis Usaha & $\begin{array}{l}\text { Perubahan } \\
\text { Pendapatan }\end{array}$ & $\begin{array}{l}\text { Perkembangan } \\
\text { usaha }\end{array}$ \\
\hline Ependi Harahap & Montir TV & $\begin{array}{l}\text { Pendapatan } \\
\text { bertambah Rp. } \\
600.000 / \text { bulan }\end{array}$ & $\begin{array}{l}\text { Tidak } \\
\text { berkembang }\end{array}$ \\
\hline $\begin{array}{l}\text { Muhammad Amri } \\
\text { Rangkuti }\end{array}$ & $\begin{array}{l}\text { Penjual Rempah- } \\
\text { rempah }\end{array}$ & $\begin{array}{l}\text { Pendapatan } \\
\text { bertambah Rp. } \\
\text { 500.00o/bulan }\end{array}$ & $\begin{array}{l}\text { Tidak } \\
\text { berkembang }\end{array}$ \\
\hline
\end{tabular}

JISFIM: Journal of Islamic Social Finance Management, Volume 2, No 2 Tahun 2021 http://jurnal.iain-padangsidimpuan.ac.id/index.php/JISFIM 


\begin{tabular}{|l|l|l|l|}
\hline Ratna Dewi & Penjual Gorengan & $\begin{array}{l}\text { Pendapatan } \\
\text { bertambah Rp. } \\
\text { 300.00o/bulan }\end{array}$ & Berkembang \\
\hline Masrianti & Penjual Kue & $\begin{array}{l}\text { Pendapatan } \\
\text { bertambah Rp. } \\
\text { 400.00o/bulan }\end{array}$ & Berkembang \\
\hline Martua Muda & Warung Kopi & $\begin{array}{l}\text { Pendapatan } \\
\text { bertambah Rp. } \\
\text { 700.000/bulan }\end{array}$ & $\begin{array}{l}\text { Tidak } \\
\text { berkembang }\end{array}$ \\
\hline
\end{tabular}

Sumber : Diolah oleh Peneliti

Berdasarkan tabel di atas bahwa rata-rata mustahik mengalami peningkatan pada pendapatannya. Walaupun peningkatannya masih tergolong jumlah yang kecil, akan tetapi sudah cukup membantu dalam memenuhi kebutuhan sehari-hari mustahik. Sedangkan dalam mengembangkan usahanya hanya terdapat dua orang mustahik yang berhasil mengembangkan usahanya. Hal ini dikarenakan, mustahik tersebut benar-benar serius menjalankan usahanya terutama memanfaatkan dengan baik dana zakat produktif yang di berikan BAZNAS Tapanuli Selatan. Akan tetapi, mustahik yang tidak berhasil mengembangkan usahanya dikarenakan mereka tidak mempunyai skill dalam mengembangkan usahanya. Dana zakat produktif yang disalurkan BAZNAS cukup besar sedangkan tidak diiringi dengan pembinaan, sehingga mustahik yang menerima dana tersebut berusaha mengembangkan usahanya, akan tetapi ditengah berjalannya usaha, mereka kebingungan tentang cara mengelola usahanya agar tetap berjalan.

Ditahun 2020 dan 2021, BAZNAS Tapanuli Selatan menyalurkan dana zakat produktif dalam bentuk usaha berkelompok yaitu binaan usaha tani dan ternak ikan. Dalam hal ini, BAZNAS Tapanuli Selatan mengadakan suatu pembinaan dan pendampingan. Akan tetapi, fakta dilapangan mustahik banyak yang mengundurkan diri dalam menjalankan usaha berkelompok ini walaupun sudah dilakukan pembinaan. Dari hasil pengamatan peneliti, bahwa pembinaan yang dilakukan BAZNAS Tapanuli Selatan tidak rutin. Pembinaan rutin perlu diadakan agar mustahik konsisten dalam menjalankan usahanya.

\section{KESIMPULAN}

Berdasarkan hasil wawancara dan observasi penelitian maka diperoleh kesimpulan bahwa peran dana zakat produktif dalam meningkatkan pendapatan mustahik di BAZNAS Tapanuli Selatan belum efektif, karena peningkatannya masih tergolong kecil. Dan pengembangan usaha setiap mustahik belum terealisasikan dengan baik. Hal ini dikarenakan BAZNAS Tapanuli Selatan hanya menyalurkan zakat produktif dan melakukan evaluasi saja, sedangkan pembinaan dan pendampingan tidak dilakukan sama sekali. Maka hal itu berdampak pada mustahik yang menjalankan usahanya tersebut. Skill yang dimiliki mustahik untuk mengelola usahanya sangat kurang, yang mengakibatkan usaha tersebut tidak berkembang bahkan tidak berjalan dengan baik.

JISFIM: Journal of Islamic Social Finance Management, Volume 2, No 2 Tahun 2021 http://jurnal.iain-padangsidimpuan.ac.id/index.php/JISFIM 


\section{DAFTAR PUSTAKA}

Annida Karima Sovia, Delima Sari Lubis, Aliman Syahuri Zein. 'Digitalisasi Pemberdayaan Ekonomi Mustahik Berbasis Zakat Produktif'. JISFIM Vol. 1 No. 1 (2020).

Arief Mufraini. Akuntansi Dan Manajemen Zakat. Jakarta: Kencana, 2008.

Asnaini. Zakat Produktif Dalam Perspektif Hukum Islam. Yogyakarta: Pustaka Pelajar, 2008.

Didin Hafidhuddin. Zakat Dalam Perekonomian Modern. Jakarta: Gema Insani, 2002.

Gazi Inayah. Teori Komprehensif Tentang Zakat Dan Pajak. Yogyakarta: PT Tiara Wacana Yogya, 2003.

Imas Rosi Nugrahani dan Richa Angkita Mulyawisdawati. 'Peran Zakat Produktif Dalam Pemberdayaan Ekonomi Mustahik (Studi Kasus Lembaga Amil Zakat Dompet Dhuafa Republika Yogyakarta 2017)'. Jurnal Ekonomi Syariah Indonesia Vol,IX, No.1 (2019).

Iwan Setiawan. "Strategi Pemberdayaan Dana Zakat Produktif Di BAZNAS Kota Bandung Dalam Meningkatkan Perekonomian Umat” Jurnal ADLIYA, Vol.10, No.2 (2016).

Lailiyatun Nafiyah. 'Pengaruh Pendayagunaan Zakat Produktif Terhadap Kesejahteraan Mustahik Pada Program Ternak Bergulir BAZNAS Kabupaten Gresik'. Jurnal El-Qist Vol.5 No. 1 (2015).

Mahyu Danil. 'Pengaruh Pendapatan Terhadap Tingkat Konsumsi Pada Pegawai Negeri Sipil Di Kantor Bupati Kabupaten Bireiuen'. Jurnal Ekonomi K, Universitas Al Muslim Vol. 4, Nomor 7 (2013): hlm. 9.

Mardani. Hukum Ekonomi Syariah Di Indonesia. Bandung: Reflika Aditama, 2011.

Mohammad Thoriquddin. Pengelolaan Zakat Produktif Perspektif Maqasid Al-Syariah Ibnu Asyur. Malang, 2015.

Muhammad Hadi. Problem Zakat Profesi \% Solusinya. Yogyakarta: Penata Aksara, 2010

Suparman Usman. Hukum Islam : Azas-Azas Pengantar Hukum Islam Dalam Tata Hukum Islam. Jakarta: Gatya Media Pratama, 2002.

Suroto. Strategi Pembangunan Dan Perencanaan Kesempatan Kerja. Yogyakarta: Gajah Mada Univercity, 2000.

JISFIM: Journal of Islamic Social Finance Management, Volume 2, No 2 Tahun 2021 http://jurnal.iain-padangsidimpuan.ac.id/index.php/JISFIM 

Pend apatan Mustahik

Sadono Sukirno. Pengantar Teori Ekonomi. Jakarta: Prada Grafindo, 2008.

Teguh Ansori. Pengelolaan Dana Zakat Produktif Untuk Pemberdayaan Mustahik Pada Lazisnu Ponorogo. Ponorogo: Jurnal Muslim Heritage Vol 3, No.1, 2018.

Wahbah AL-Zuhayly. Zakat Kajian BerbagaiMazhab. Bandung: PT Remaja Rosdakarya, 1995 .

Yusuf Qaradhawi. Fiqih Zakat. Jakarta: Litera Antar Nusa, 2005. 